\title{
The Effect of Histamine and Cyclic Adenosine Monophosphate on Myosin Light Chain Phosphorylation in Human Umbilical Vein Endothelial Cells
}

\author{
Alan B. Moy, Sandra S. Shasby, Brooke D. Scott, and D. Michael Shasby \\ Department of Medicine, University of Iowa College of Medicine, and Veterans Administration Hospital, Iowa City, Iowa 52242
}

\begin{abstract}
Histamine causes adjacent endothelial cells to retract from each another. We examined phosphorylation of the 20-kD myosin light chain (MLC $\mathbf{C}_{20}$ ) in human umbilical vein endothelial cells (HUVECs) exposed to histamine to determine if we could find evidence to support the hypothesis that retraction of these cells in response to histamine represents an actomyosininitiated contraction of the endothelial cytoskeleton. We found that MLC $_{20}$ in HUVECs was constitutively phosphorylated with $\sim 0.2 \mathrm{~mol}$ phosphate $/ \mathrm{mol} \mathrm{MLC}_{20}$. Histamine increased $\mathrm{MLC}_{20}$ phosphorylation by $0.18 \pm 0.05 \mathrm{~mol}$ phosphate $/ \mathrm{mol}$ $\mathrm{MLC}_{20}$. This peak increase in phosphorylation occurred $30 \mathrm{~s}$ after initiating histamine exposure, persisted through $90 \mathrm{~s}$, and returned to control levels by $5 \mathrm{~min}$. Agents that increase HUVEC CAMP prevent cell retraction in response to histamine. An increase in HUVEC cAMP decreased $M_{20}$ phosphorylation by $0.18 \pm 0.02 \mathrm{~mol}$ phosphate $/ \mathrm{mol} \mathrm{MLC}_{20}$ and prevented the increase in $\mathrm{MLC}_{20}$ phosphorylation after exposure to histamine. Tryptic peptide maps of phosphorylated myosin light chain indicated that myosin light chain kinase phosphorylated MLC $_{20}$ in HUVECs under basal, cAMP-, and histamine-stimulated conditions. Phosphoaminoacid analysis of the monophosphorylated peptide indicated that, in contrast to smooth muscle cells, $\operatorname{ser}^{19}$ and thr ${ }^{18}$ monophosphorylation occurs in HUVECs. On the basis of our results, modulation of myosin light chain kinase activity may be an important regulatory step in the control of endothelial barrier function. (J. Clin. Invest. 1993. 92:1198-1206.) Key words: myosin • phosphorylation • endothelial • histamine $\bullet$ cAMP
\end{abstract}

\section{Introduction}

Edema caused by molecules such as histamine is associated with the separation of adjacent endothelial cells from one another (1-8). Although there are multiple reports documenting this phenomenon, the mechanism of cell separation remains incompletely understood.

Agents that disrupt actin filaments or that chelate calcium and breakdown calcium-dependent cell-cell and cell-substrate adhesion cause edema and separation of adjacent endothelial cells $(6,7,9)$. These data demonstrate that separation may

Address correspondence and reprint requests to Dr. Michael S. Shasby, Department of Internal Medicine, University of Iowa College of Medicine, Iowa City, IA 52242.

Received for publication 12 October 1992 and in revised form 2 April 1993.

J. Clin. Invest.

(C) The American Society for Clinical Investigation, Inc.

0021-9738/93/09/1198/09 \$2.00

Volume 92, September 1993, 1198-1206 result from loss of tethering between cells and between cells and substrate. They also suggest that constitutive centripetal intracellular cytoskeletal tension opposes these normal tethering forces, and unopposed expression of a constitutive tension may account for cell retraction when tethering forces are released.

Others have suggested that the separation of adjacent endothelial cells from each other involves initiation of an active contraction mediated by actin and myosin $(10,11)$. Support for this hypothesis comes from two observations. First, Wysolmerski and Lagunoff (12) found that retraction of endothelial cells exposed to histamine was prevented if the cells were depleted of ATP before exposure to histamine. Second, $100 \mu \mathrm{M}$ calcium, ATP, myosin light chain kinase (MLCK), ${ }^{1}$ and calmodulin caused phosphorylation of the $20-\mathrm{kD}$ myosin light chain $\left(\mathrm{MLC}_{20}\right)$ and contraction of the cytoskeleton of endothelial cells after their cell membranes were removed with detergents $(10,11,13)$.

Endothelial cell retraction in response to histamine is well documented (4). When histamine binds to an $\mathrm{H}_{1}$ receptor on an endothelial cell it initiates a signal transduction cascade that results in an increase in cell calcium and diacylglycerol (DAG) (2). The increase in cell calcium and DAG could stimulate an acute increase in MLC $_{20}$ phosphorylation by MLCK (calcium dependent) or by protein kinase C (PKC) (calcium and DAG dependent). The acute increase in light chain phosphorylation could then increase actomyosin contraction and centripetal tension (14-16).

In the experiments described in this manuscript we investigated the effects of histamine on phosphorylation of $\mathrm{MLC}_{20}$ in human umbilical vein endothelial cells (HUVECs). We were interested to determine if $\mathrm{MLC}_{20}$ was constitutively phosphorylated, if histamine acutely increased $\mathrm{MLC}_{20}$ phosphorylation in HUVECs, and, if so, how much phosphorylation of $\mathrm{MLC}_{20}$ increased. Because $\mathrm{MLC}_{20}$ phosphorylation is mediated by both MLCK and PKC in other nonmuscle cells, we also constructed tryptic peptide maps of the phosphorylated $\mathrm{MLC}_{20}$ to directly determine which kinase was responsible for $\mathrm{MLC}_{20}$ phosphorylation in HUVECs, constitutively and after stimulation with histamine (15). We previously found that increasing cell cAMP prevented HUVECs from retracting in response to histamine, but the increase in cAMP did not prevent the increase in cell calcium (2). In other cells, one of the effects of increased cell cAMP is to inhibit MLC $_{20}$ phosphorylation by MLCK (17). Hence, we were also interested in determining if increased cell cAMP prevents increased $\mathrm{MLC}_{20}$ phosphorylation in histamine-stimulated HUVECs. If it does, it would, in part, explain how cAMP prevents the response of HUVECs to histamine.

1. Abbreviations used in this paper: DAG, diacylglycerol; HUVEC, human umbilical vein endothelial cells; $\mathrm{MLC}_{20}, 20-\mathrm{kD}$ myosin light chain kinase; MLCK, myosin light chain kinase; PKC, protein kinase $C$. 


\section{Methods}

Materials. Tissue culture supplies were obtained from the Cancer Center, University of Iowa. Fetal bovine serum was obtained from Hyclone Laboratories, Inc. (Logan, UT). Polyclonal rabbit IgG antimyosin antibody against human platelet whole myosin was obtained from Biomedical Technologies, Inc. (Stoughton, MA). Protein A, Staphylococcus aureus cell suspension was obtained from Calbiochem Corp. (San Diego, CA). Rat brain PKC was obtained from Calbiochem Corp. Histamine, theophylline, 8-bromo cAMP, DL-histidine, DL-glutamic acid, phosphoserine, and phosphothreonine were obtained from Sigma Chemical Co. (St. Louis, MO). L-1- $p$-tosylamino2-phenylethyl chloromethyl ketone (TPCK) trypsin was from Worthington Biochemical Corp. (Freehold, NJ). [32 P]Orthophosphate and $\gamma-\left[{ }^{32} \mathrm{P}\right]$ ATP were obtained from New England Nuclear (Boston, MA). $\left[{ }^{35} \mathrm{~S}\right]$ Methionine was obtained from ICN Radiochemicals (Irvine, CA). Transwells were purchased through Costar Corp. (Cambridge, MA). Smooth muscle MLCK and turkey gizzard MLC were gifts from Dr. James Sellers, National Heart, Lung, and Blood Institute (Bethesda, MD). All other chemicals were reagent grade.

Cell culturing. Cultured HUVECs were prepared by collagenase treatment of freshly obtained umbilical veins as described (2). For experiments designed to measure the amount of phosphorylated $\mathrm{MLC}_{20}$ and for some of the experiments designated for peptide mapping, harvested cells were plated on $25-\mathrm{mm}$ diameter polycarbonate filters $(0.8-\mu \mathrm{m}$ pore size $)$ precoated with $30 \mu \mathrm{g} / \mathrm{ml}$ of fibronectin as described (2). Alternatively, harvested cells were plated on $60-\mathrm{mm}$ diameter tissue culture plates (Costar Corp.) precoated with $1 \%$ gelatin for some of the peptide mapping experiments. There was no difference in the peptide maps of cells grown on micropore filters when compared with cells grown on tissue culture plastic. However, basal phosphorylation was higher $(\sim 0.2 \mathrm{~mol}$ phosphate $/ \mathrm{mol}$ light chain $)$ in cells grown on tissue culture plastic than in cells grown on micropore filters $(n>25$ for each). All cells were cultured in medium 199 and supplemented with $20 \%$ fetal bovine serum, basal medium Eagle vitamins and amino acids, glucose $(5 \mathrm{mM})$, glutamine $(2 \mathrm{mM})$, penicillin $(100 \mu / \mathrm{ml})$, and streptomycin $(100 \mu \mathrm{g} / \mathrm{ml})$. All studies were performed on primary cultures that were $2 \mathrm{~d}$ postconfluent at the time of study. Cultures were identified as endothelial cells by their characteristic uniform morphology, uptake of acetylated LDL ( 99\% of cells), and by indirect immunofluorescent staining for factor VIII ( $\sim 97 \%$ of cells $)$. Because the cells are not visible on the polycarbonate filters, for each experiment, a control well was plated and examined for morphology to be certain that the morphology was consistent with that of cells identified as endothelial cells by these staining techniques.

Purification of human platelet myosin $M L C_{20}$. Human platelet $\mathrm{MLC}_{20}$ was purified from whole platelet myosin using the procedure described by Daniel and Adelstein (18). Preparations were used if contaminating kinases were not present. Whole-platelet myosin was purified according to Sellers et al. (19). Whole-platelet myosin was not a suitable substrate for generating in vitro peptide map standards because it contained contaminating endogenous kinases.

Isotopic labeling and stimulation. Cells designated for quantitating $\mathrm{MLC}_{20}$ phosphorylation were grown on micropore filters and were labeled with $1.5 \mathrm{ml}\left[{ }^{35} \mathrm{~S}\right]$ methionine $(555 \mu \mathrm{Ci} / \mathrm{ml})$ in $\mathrm{M} 199$ with $10 \%$ fetal bovine serum for $48 \mathrm{~h}$ at $37^{\circ} \mathrm{C}$ and $5 \% \mathrm{CO}_{2}$. Labeling in $<10 \%$ fetal bovine serum increased basal phosphorylation of $\mathrm{MLC}_{20}$.

Cells designated for peptide mapping were grown on either micropore filters or tissue culture plates. Confluent cells were washed three times with a phosphate-free buffer with the following composition $\left(\mathrm{mM}\right.$ ): $119 \mathrm{NaCl}, 5 \mathrm{KCl}$, 5.6 glucose, $0.4 \mathrm{MgCl}_{2}, 1 \mathrm{CaCl}_{2}, 25$ Pipes ( $\mathrm{pH}$ 7.2 , and were then labeled with $3 \mathrm{ml}$ of $300-400 \mu \mathrm{Ci} / \mathrm{ml} \mathrm{[}{ }^{32} \mathrm{P}$ ]orthophosphate for $2 \mathrm{~h}$ at $37^{\circ} \mathrm{C}$ without $\mathrm{CO}_{2}$.

Labeled cells were exposed to either buffer, histamine $\left(10^{-5} \mathrm{~mol} /\right.$ liter), or a mixture of agents used to increase cell cAMP (8-bromocAMP, $10^{-4} \mathrm{~mol} /$ liter, forskolin, $2 \times 10^{-5} \mathrm{~mol} /$ liter, and theophylline, $10^{-3} \mathrm{~mol} /$ liter) with or without histamine. There was no difference in $\mathrm{MLC}_{20}$ phosphorylation between cells exposed to the mixture of agents to increase cAMP versus 8-bromo-cAMP alone, and these groups were combined for analysis.

Reactions were terminated by snap freezing on a dry ice methanol bath and the cells were lysed by thawing in $1 \mathrm{ml}$ of a buffer containing $1 \% \mathrm{NP}-40,100 \mathrm{mM}$ sodium pyrophosphate, $250 \mathrm{mM} \mathrm{NaCl}, 50 \mathrm{mM}$ $\mathrm{NaF}, 5 \mathrm{mM}$ EGTA, $0.1 \mathrm{mM}$ PMSF, $10 \mu \mathrm{g} / \mathrm{ml}$ leupeptin, $15 \mathrm{mM} \beta$ mercaptoethanol, and $20 \mathrm{mM}$ Tris- $\mathrm{HCl}(\mathrm{pH} 7.9)$. The lysate was sediment at $100,000 \mathrm{~g}$ for $5 \mathrm{~min}$ at $4^{\circ} \mathrm{C}$, and the supernatant was incubated with $20 \mu$ l of rabbit anti-human platelet myosin antibody $(2 \mathrm{mg} / \mathrm{ml})$ at $4^{\circ} \mathrm{C}$ for $1 \mathrm{~h} .50 \mu \mathrm{l}$ of a prewashed $S$. aureus cell suspension (Pansorbin) was then added to the suspension, which was incubated for an additional $30 \mathrm{~min}$ at $4^{\circ} \mathrm{C}(20)$. The mixture was centrifuged $(100,000$ $g$ for $1 \mathrm{~min}$ ) and the pellet was washed with $0.5 \mathrm{ml}$ of the lysing buffer and recentrifuged. The pellet was then washed with $0.5 \mathrm{ml}$ of a 50:50 mixture of lysing buffer and PBS. The pellet was resuspended in $200 \mu \mathrm{l}$ of SDS sample buffer for SDS-PAGE or $35 \mu$ l of urea-lysing buffer for two-dimensional electrophoresis.

Isoelectric focusing. The unphosphorylated and phosphorylated $\mathrm{MLC}_{20}$ isoforms were separated by two-dimensional electrophoresis as described by Ludowyke et al. (15) but with the following modifications. The sample was suspended in $35 \mu \mathrm{l}$ of a buffer containing $9.5 \mathrm{M}$ urea (ultrapure urea; Boehringer Mannheim Corp., Indianapolis, IN), NP-40, $0.04 \%$ pharmalyte ( $\mathrm{pH} 4.5-5.4), 0.04 \%$ pharmalyte $(\mathrm{pH}$ 4-6.5) and 0.1 M DTT. Tube gels were prepared using $1.5 \mathrm{~mm}$ i.d. $\times$ 180 -mm glass tubes. For 10 tubes, $2.78 \mathrm{~g}$ of ultra pure urea was mixed with $1.5 \mathrm{ml}$ of $\mathrm{H}_{2} \mathrm{O}, 0.83 \mathrm{ml}$ of $30 \%: 0.8 \%$ acrylamide/bisacrylamide,

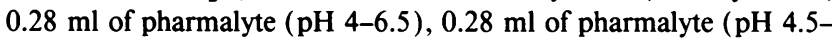
5.4 ), and $0.28 \mathrm{ml}$ of CHAPS buffer ( $100 \mathrm{mg}$ CHAPS, $0.3 \mathrm{ml} \mathrm{H}_{2} \mathrm{O}$, and $0.03 \mathrm{ml} \mathrm{NP}-40$ ). Gels were drawn to a height of $150 \mathrm{~mm}$. Gels were polymerized with $5 \mu \mathrm{l}$ of TEMED and $10 \mu \mathrm{l}$ ammonium persulfate. Isoelectric focusing was performed using a cell (model 175; Bio-Rad Laboratories (Richmond, CA).

The anolyte contained $0.01 \mathrm{M}$ glutamic acid and the catholyte contained $0.01 \mathrm{M}$ histidine. Gels were prefocused at $25^{\circ} \mathrm{C}$ at $200 \mathrm{~V}$ for $2 \mathrm{~h}$ followed by $500 \mathrm{~V}$ for $5 \mathrm{~h}$. 30- $\mu$ l samples were loaded onto the gel, covered with $10 \mu \mathrm{l}$ of an overlaying buffer, which contained $8 \mathrm{M}$ urea, $2 \%$ pharmalyte ( $\mathrm{pH} 3-10$ ), and $0.5 \%$ pharmalyte ( $\mathrm{pH} 4.5-5.4)$. Catholyte buffer was layered over the overlaying buffer. The samples were then electrophoresed at $2,500 \mathrm{~V}$ for an additional $32,000 \mathrm{~V} \mathrm{~h}$.

Second Dimension SDS-PAGE. Tube gels were extracted and rinsed with transfer solution ( $3 \% \mathrm{SDS}, 0.07 \mathrm{M}$ Tris-Base ( $\mathrm{pH}$ 6.7), and $0.03 \mathrm{mg} / \mathrm{ml}$ bromphenol blue), layered onto a polyacrylamide/bisacrylamide slab gel (15\%:0.4\%), and sealed to the slab gel with hot agar (2.3\% SDS, $0.062 \mathrm{M}$ Tris-Base ( $\mathrm{pH} 6.8$ ), $0.5 \%$ agarose, and $5 \% \beta$-mercaptoethanol). The gels were run at $4^{\circ} \mathrm{C}$ for 18 to $20 \mathrm{~h}$ at $200 \mathrm{~V}$. Gels were treated with $\mathrm{En}^{3}$ hance (Dupont Pharmaceuticals Inc., Wilmington, DE) to accelerate autoradiograph development. Autoradiographs were developed using Kodak X-OMAT AR film. The relative isoform distribution was quantitated using an Image Quant laser densitometer (Molecular Dynamics, Sunnyvale, CA).

Two-dimensional peptide mapping of myosin tryptic peptides. Immunoprecipitate from ${ }^{32} \mathrm{P}$-labeled HUVECs was dissolved in SDS sample buffer as above and separated by an $8-15 \%$ polyacrylamide gradient gel, and electrophoresed at $200 \mathrm{~V}$ for 4 to $5 \mathrm{~h}$ at $21^{\circ} \mathrm{C}$. The ${ }^{32} \mathrm{P}$-labeled $\mathrm{MLC}_{20}$ was cut from the wet gel into small pieces and washed three times for 30 min with $40 \%$ methanol, $10 \%$ acetic acid, and $50 \%$ water, and then an additional three times with $10 \%$ methanol for the same time period. The washed gel slices were subsequently dried under nitrogen and then digested with $1 \mathrm{ml}$ of $60 \mu \mathrm{g} / \mathrm{ml}$ of TPCK-trypsin in 50 $\mathrm{mM}$ ammonium bicarbonate at $37^{\circ} \mathrm{C}$ for $4 \mathrm{~h}$. The digest was collected and stored at $4^{\circ} \mathrm{C}$. The remaining gel was further digested with $1 \mathrm{ml}$ of $30 \mu \mathrm{g} / \mathrm{ml}$ trypsin for an additional $20 \mathrm{~h}$. Digests were pooled and lyophilized. Peptides were resuspended in $1 \mathrm{ml}$ of water and lyophilized.

Digest was resuspended with $30 \mu \mathrm{l}$ of electrophoresis buffer (acetic acid/formic acid/water, 9:3:88), spotted on a plastic $20 \times 20 \times 0.20$ mm silica P 60 TLC plate (EM Science, Gibbstown, NJ). Peptides were electrophoresed toward the cathode at $900 \mathrm{~V}$ at $4^{\circ} \mathrm{C}$ for $45 \mathrm{~min}$ using the technique described by Gracy (21). Peptide migration was 
monitored by the movement of acid fuschin dye toward the anode. Plates were then dried and subjected to ascending chromatography using 1-butanol/acetic acid/pyridine/water (49:8:38:30). Plates were then dried, wrapped in cellophane, and autoradiographs were developed using Kodak X-Omat AR film.

Phosphoamino acid analysis. Peptides that were generated from two-dimensional TLC maps were scraped from the TLC plate and eluted with $50 \mathrm{mM} \mathrm{NH} \mathrm{NHCO}_{3}$. The peptide was then lyophilized, washed with water, and lyophilized again to remove the ammonium bicarbonate. Peptides were subjected to acid hydrolysis in $6 \mathrm{~N} \mathrm{HCl}$ at $120^{\circ} \mathrm{C}$ for $3 \mathrm{~h}$ and then relyophilized. Dry residue was washed with water and relyophilized. Labeled phosphoamino acids were resuspended in electrophoresis buffer (acetic acid/formic acid/water, 9:3:88), which contained $2 \mu \mathrm{g} / \mu \mathrm{l}$ of phosphothreonine and phosphoserine, and were then spotted onto a TLC plate. Amino acids were subjected to electrophoresis at $700 \mathrm{~V}$ for $2 \mathrm{~h}$ and $50 \mathrm{~min}$ at $4^{\circ} \mathrm{C}$. Labeled phosphoamino acids were detected by autoradiography and identified by comparing the corresponding migration of the phosphoamino acid standards, which were stained with ninhydrin.

Measurement of intracellular CAMP. HUVECs plated on polycarbonated filters were exposed to control media (M199 without serum), histamine $\left(10^{-5} \mathrm{M}\right)$, or cAMP mixture (forskolin $\left[2 \times 10^{-5} \mathrm{M}\right]$ and theophylline $\left.\left[10^{-3} \mathrm{M}\right]\right)$. After the indicated time intervals, the medium was aspirated and the cells were extracted twice with $1 \mathrm{ml}$ of ethanol. The extracts were combined and centrifuged at $3,000 \mathrm{~g}$ for $15 \mathrm{~min}$ at $4^{\circ} \mathrm{C}$. The supernates were dried under nitrogen and reconstituted in the sample buffer provided (cAMP ${ }^{3} \mathrm{H}$ Assay System; Amersham Corp., Arlington Heights, IL). The rest of the analysis system was conducted as described in the directions for the assay system.

In vitro phosphorylation assays. Standards for tryptic peptide maps of $\mathrm{MLC}_{20}$ were generated in vitro from turkey gizzard $\mathrm{MLC}_{20}$ or platelet $\mathrm{MLC}_{20}$ phosphorylated with either smooth muscle MLCK or rat brain PKC. Phosphorylation of MLC by MLCK was carried out in a volume of $200 \mu \mathrm{l}$ using $20 \mathrm{mM}$ Tris- $\mathrm{HCl}$ ( $\mathrm{pH} \mathrm{7.6),} 5 \mathrm{mM} \mathrm{MgCl}, 200$ $\mu \mathrm{M} \mathrm{CaCl}, 1 \mathrm{mM}\left[\gamma^{-}{ }^{32} \mathrm{P}\right]$ ATP $(400-1,000 \mathrm{cpm} / \mathrm{pmol}), 2 \mu \mathrm{M}$ calmodulin, $7 \mu \mathrm{g} / \mathrm{ml} \mathrm{smooth} \mathrm{muscle} \mathrm{MLCK,} \mathrm{and} 3.25 \mathrm{mg} / \mathrm{ml}$ turkey gizzard smooth muscle $\mathrm{MLC}_{20}$ or $50 \mu \mathrm{g} / \mathrm{ml}$ human platelet $\mathrm{MLC}_{20}$. The reaction was initiated with ATP at $25^{\circ} \mathrm{C}$ for 10 min and terminated by precipitating the assay mixture with $40 \mu 1$ 100\% TCA. Samples were microcentrifuged, and the precipitate was washed three times with $1 \mathrm{ml}$ of $10 \%$ TCA. The pellet was resuspended with $200 \mu \mathrm{l}$ of SDS-sample buffer and $0.1 \%$ bromphenol blue and made alkaline with $1 \mathrm{~N} \mathrm{NaOH}$.

Phosphorylation of $\mathrm{MLC}_{20}$ by PKC was carried out in a final volume of $400 \mu$ l using $20 \mathrm{mM}$ Tris- $\mathrm{HCl}$ ( $\mathrm{pH} 7.6$ ), $5 \mathrm{mM} \mathrm{MgCl} 2,200 \mu \mathrm{M}$ $\mathrm{CaCl}_{2}, 1 \mathrm{mM}\left[\gamma^{-32} \mathrm{P}\right]$ ATP $(400-1,000 \mathrm{cpm} / \mathrm{pmol}), 50 \mu \mathrm{g} / \mathrm{ml}$ phosphatidylserine, $0.8 \mu \mathrm{g} / \mathrm{ml} 1,3$ diolein, and $2.7 \mu \mathrm{g} / \mathrm{ml} \mathrm{PKC} \mathrm{at} 30^{\circ} \mathrm{C}$ for $60 \mathrm{~min}$. Phospholipids were stored in chloroform and evaporated under a constant stream of nitrogen. Phospholipids were then resuspended in Tris buffer and sonicated at $4^{\circ} \mathrm{C}$ for 5 min using a sonicator (model 200; Branson Ultrasonics Corp., Danbury, CT). The reaction was initiated with the labeled ATP.

Calculating the stoichiometry of $M L C_{20}$ phosphorylation. Quantitative phosphorylation of $\mathrm{MLC}_{20}$ was determined using laser densitometry of autoradiographs made from the two-dimensional gels of ${ }^{35} \mathrm{~S}$-la- beled $\mathrm{MLC}_{20}$ immunoprecipitated from the cells. There were two phosphorylated isoforms of $\mathrm{MLC}_{20}$ (designated A and B) and each phosphorylated isoform could exist as an unphosphorylated ( $A$ or $B$ ), monophosphorylated $\left(A^{\prime}\right.$ or $\left.B^{\prime}\right)$, or diphosphorylated $\left(A^{\prime \prime}\right.$ or $\left.B^{\prime \prime}\right)$ isoform. The volume $(V)$ of each phosphorylation state of each isoform was integrated on the densitometer. The volume of each phosphorylation state for each of the isoforms was then expressed as a fraction ( $\mathrm{fxn}$ ) of the total radioactivity for that isoform, for example, fraction $A$ $=V(A) / V(A)+V\left(A^{\prime}\right)+V\left(A^{\prime \prime}\right)$. Fractions for $B$ isoforms were calculated similarly. Phosphorylation stoichiometry was then calculated by the following formula: mol phosphate/mol isoform $A=F x n A^{\prime}+2$ $\times$ Fxn $A^{\prime \prime}$ and mol phosphate $/ \mathrm{mol}$ isoform $B=$ Fxn $B^{\prime}+2 \times$ Fxn $B^{\prime \prime}$.

Statistical analysis. Data are reported as means \pm standard errors (SE). Comparisons between two groups were made using the Student's $t$ test. Comparisons between more than two groups were made using analysis of variance and individual groups comparisons were done using a Tukey honest significance difference test for post hoc comparisons of means. Differences were considered significant at the $P \leq 0.05$ level.

\section{Results}

\section{Identification of MLC isoforms in HUVECs}

MLC isoforms from HUVECs were separated by two-dimensional gel electrophoresis. Fig. $1 A$ is an autoradiograph of a two-dimensional gel of immunoprecipitated MLC from unstimulated HUVECs labeled with [ $\left.{ }^{35} \mathrm{~S}\right]$ methionine. Isoforms were observed at three molecular masses, 20, 19.7, and $16 \mathrm{kD}$. The most basic of the 20 - and 19.7-kD isoforms were unphosphorylated as they were not detectable in ${ }^{32} \mathrm{P}$-labeled cells (Fig. $1 B$ ). Similarly, the $16-\mathrm{kD}$ isoforms were unphosphorylated as they were also not observed in ${ }^{32} \mathrm{P}$-labeled cells (Fig. $1 \mathrm{~B}$ ). Kawamoto et al. (14) also found 20- and 19.7-kD phosphorylated isoforms and a $16-\mathrm{kD}$ isoform in platelets. Unlike human platelet and smooth muscle MLC, the unphosphorylated A and $B$ isoforms of HUVECs are focused adjacent to each other $(14,22)$. Also, the $16-\mathrm{kD}$ isoform existed at only one isoelectric point in human platelets whereas in HUVECs there are two 16-kD isoforms with distinct isoelectric points (Fig. 1 $A$ ).

The 20- and the 19.7-kD isoforms each focused at three distinct isoelectric points, corresponding to the unphosphorylated, monophosphorylated, and diphosphorylated states of each isoform. The unphosphorylated isoforms were focused toward the basic end where isoform $B$ had a higher molecular mass and more acidic isoelectric point than isoform $A$. The corresponding mono- and diphosphorylated isoforms of $\mathrm{A}$ and $B$ were focused toward the acidic end and were arbitrarily designated $\mathrm{A}^{\prime}, \mathrm{B}^{\prime}$ and $\mathrm{A}^{\prime \prime}, \mathrm{B}^{\prime \prime}$, respectively (Fig. $1 A$ ). We confirmed the identity of the unphosphorylated isoforms in ${ }^{35} \mathrm{~S}$-labeled cells by depleting cells of ATP using antimycin A and deoxyglucose (23). ATP depletion generated two isoforms, which corre-
${ }^{35}$ S-labelled

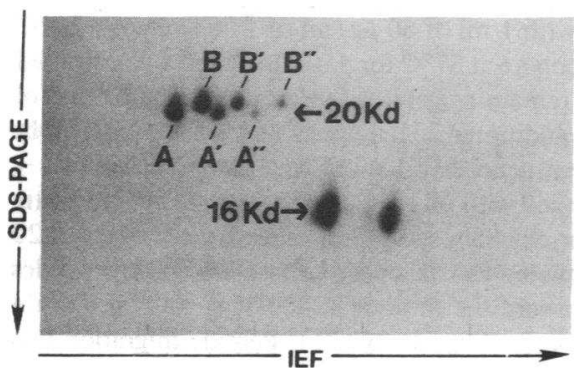

32P-labelled

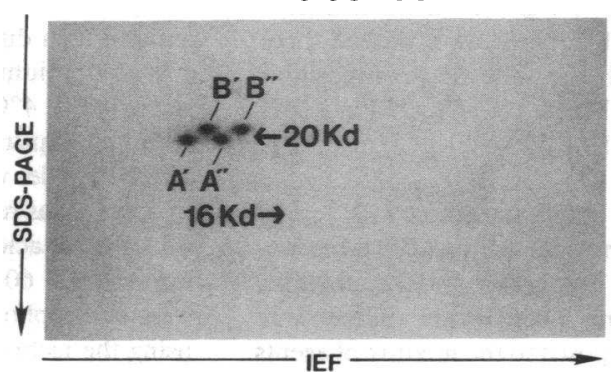

Figure 1. (A) Autoradiograph of immunoprecipitated MLC isoforms from ${ }^{35}$ S-labeled HUVECs. The isoforms were separated by two-dimensional gel electrophoresis. Isoforms existed in unphosphorylated ( $A$ and $B$ ), monophosphorylated $\left(A^{\prime}\right.$ and $\left.B^{\prime}\right)$, and diphosphorylated ( $A^{\prime \prime}$ and $\left.B^{\prime \prime}\right)$ states with distinct isoelectric points. $(B)$ Autoradiograph of immunoprecipitated MLC isoforms from ${ }^{32} \mathrm{P}$-labeled HUVECs. See text for explanation. 
Control

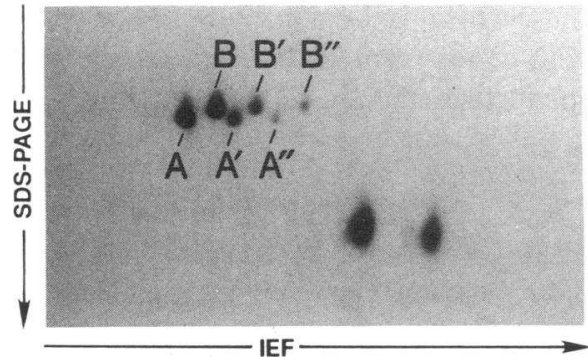

CAMP

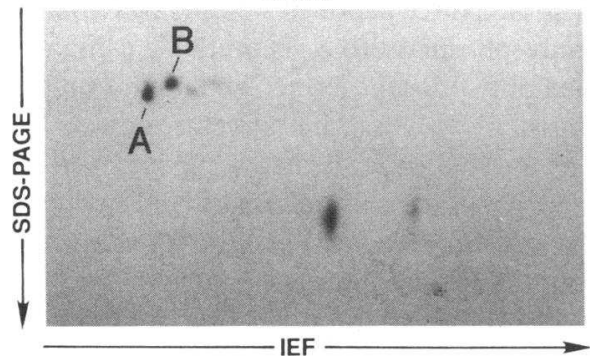

Histamine

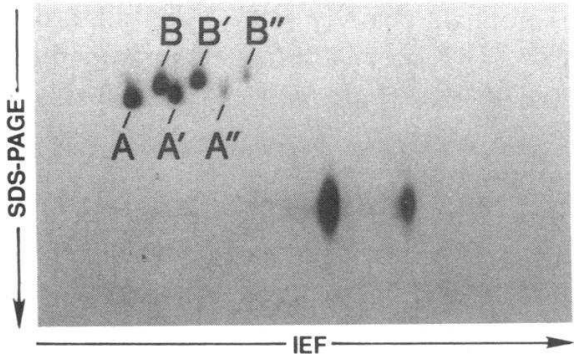

cAMP + Histamine

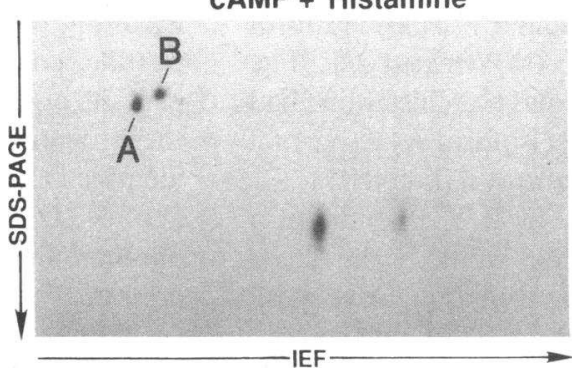

Figure 2. (A) Autoradiograph of immunoprecipitated MLC isoforms from control ${ }^{35} \mathrm{~S}$-labeled HUVECs. $(B)$ Autoradiograph of immunoprecipitated MLC isoforms from ${ }^{35} \mathrm{~S}$-labeled HUVECs exposed to histamine $\left(10^{-5} \mathrm{~mol} /\right.$ liter $\left.\times 30 \mathrm{~s}\right) .(C)$ Autoradiograph of immunoprecipitated MLC isoforms from ${ }^{35} \mathrm{~S}$-labeled HUVECs exposed to $8 \mathrm{Br}$ cAMP $\left(10^{-4} \mathrm{~mol} /\right.$ liter $\left.\times 10 \mathrm{~min}\right)$. (D) Autoradiograph of immunoprecipitated MLC isoforms from ${ }^{35} \mathrm{~S}$-labeled HUVECs preexposed to $8 \mathrm{Br}$ $\operatorname{cAMP}\left(10^{-4} \mathrm{~mol} /\right.$ liter $\left.\times 10 \mathrm{~min}\right)$ and then exposed to histamine $\left(10^{-5}\right.$ $\mathrm{mol} /$ liter) for $30 \mathrm{~s}$. See text for explanation. sponded to the unphosphorylated isoforms A and B (data not shown). The identity of the mono- and diphosphorylated isoforms were confirmed by separation of the isoforms from cells labeled with ${ }^{32} \mathrm{P}$ (Fig. $1 \mathrm{~B}$ ).

\section{Quantitating phosphorylation of myosin light chain}

The effect of histamine on $M L C_{20}$ phosphorylation. Histamine $\left(10^{-5} \mathrm{M}\right)$ induced a rapid but transient increase in $\mathrm{MLC}_{20}$ phosphorylation. This was evident as a relative increase in the intensity of $\mathrm{MLC}_{20}$ that migrated as mono- and diphosphorylated isoforms (Fig. 2, $A$ and $B$ ). In unstimulated cells, the intensity of unphosphorylated $\mathrm{MLC}_{20}$ isoforms (A and B) greatly exceeds the corresponding intensity of the monophosphorylated isoforms $\left(\mathrm{A}^{\prime}\right.$ and $\left.\mathrm{B}^{\prime}\right)$. In contrast, in HUVECs exposed to histamine, the intensity of the unphosphorylated $\mathrm{MLC}_{20}$ isoforms is almost equal to the intensity of the corresponding monophosphorylated isoforms. This indicates that increased $\mathrm{MLC}_{20}$ phosphorylation occurs when HUVECs are exposed to histamine.

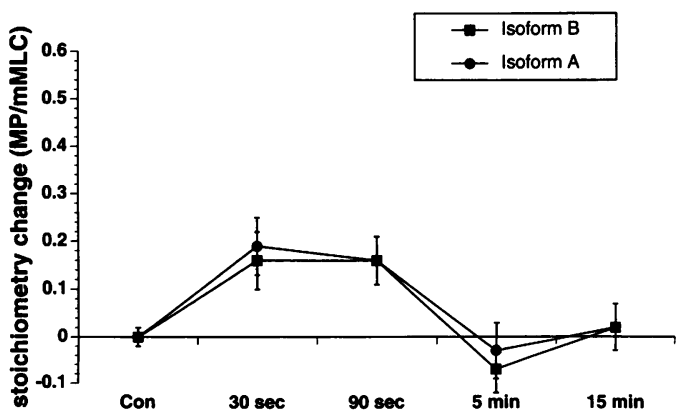

Figure 3. This figure demonstrates the effect of histamine on $\mathrm{MLC}_{20}$ phosphorylation over time. Data are expressed as a change in stoichiometry ( $\mathrm{mol} \mathrm{P} / \mathrm{mol} \mathrm{MLC}_{20}$ ) from control HUVECs. Stoichiometric change is reported for control HUVECs and HUVECs exposed to histamine for $30 \mathrm{~s}, 90 \mathrm{~s}, 5 \mathrm{~min}$, and $15 \mathrm{~min}$. Histamine $\left(10^{-5} \mathrm{~mol} /\right.$ liter) increased the amount of $\mathrm{MLC}_{20}$ phosphorylation at 30 and 90 $s(P<0.05) . n \geq 15$ for each time point and condition.
Expressed as stoichiometry, histamine induced a modest increase in the number of mol phosphate $/ \mathrm{mol} \mathrm{MLC}_{20}$ in HUVECs (Fig. 3). $30 \mathrm{~s}$ after exposure to histamine $\mathrm{MLC}_{20}$ phosphorylation was $0.16 \pm 0.05$ (isoform $B$ ) and $0.19 \pm 0.05$ (isoform A) mol phosphate/mol light chain greater in histamineexposed cells than in control cells. This represented the peak increase in histamine-stimulated phosphorylation. The increased phosphorylation of $\mathrm{MLC}_{20}$ persisted through $90 \mathrm{~s}$ when $\mathrm{MLC}_{20}$ phosphorylation in histamine-exposed cells was $0.16 \pm 0.04$ (isoform B) and $0.17 \pm 0.04$ (isoform A) mol phosphate/mol light chain greater than it was in control cells. However, by 5 min MLC $_{20}$ phosphorylation in histamine-exposed cells was no longer different than it was in control cells, and it remained at the control level $15 \mathrm{~min}$ after histamine exposure.

Ionomycin produced a much greater increase in $\mathrm{MLC}_{20}$ phosphorylation than did histamine (Fig. 4). $90 \mathrm{~s}$ after initiating exposure to $5 \times 10^{-6} \mathrm{M}$ ionomycin $\mathrm{MLC}_{20}$ phosphoryla-

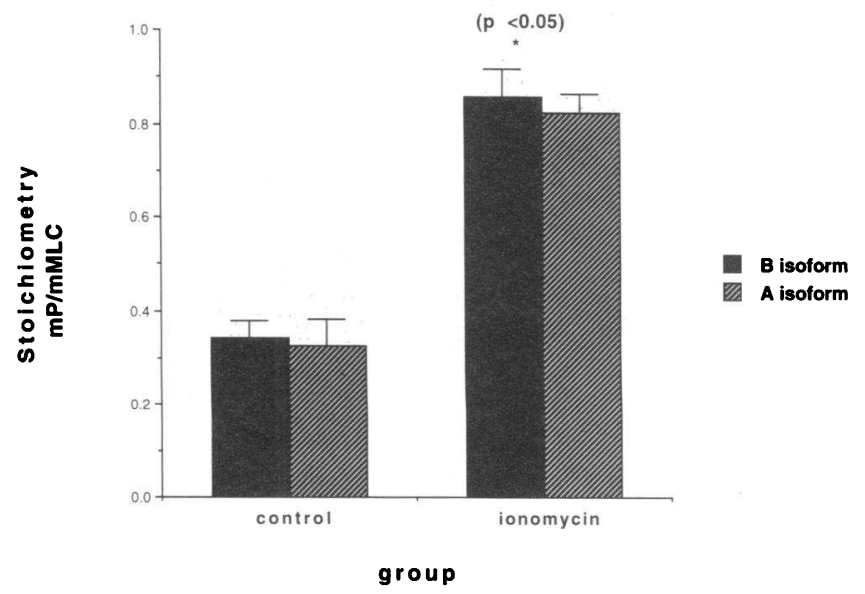

Figure 4. MLC ${ }_{20}$ phosphorylation in control HUVECs and HUVECs treated with $5 \mu \mathrm{M}$ ionomycin $(90 \mathrm{~s})$. Ionomycin increased $\mathrm{MLC}_{20}$ phosphorylation by $0.5 \mathrm{~mol}$ phosphate $/ \mathrm{mol} \mathrm{MLC}_{20}(P<0.05, n=6$ for each). 
tion in HUVECs increased $0.51 \pm 0.06$ (isoform B) and $0.50 \pm 0.04$ (isoform A) mol phosphate $/ \mathrm{mol}$ light chain $(n=4$ control and 6 ionomycin monolayers).

The effect of increasing intracellular cAMP on $M L C_{20}$ phosphorylation. Increasing cAMP in HUVECs decreased $\mathrm{MLC}_{20}$ phosphorylation and prevented histamine from increasing phosphorylation above levels found in control cells. cAMP alone shifted the isoform distribution toward the unphosphorylated isoforms and, in histamine-exposed cells, cAMP pretreatment prevented the expected shift towards the mono- and diphosphorylated isoforms (Figs. 2, $C$ and $D$ ). This shift in the isoform distribution represented a decrease in $\mathrm{MLC}_{20}$ phosphorylation of $0.19 \pm 0.02$ (isoform $B$ ) and $0.17 \pm 0.02$ (isoform A) mol phosphate/mol light chain in cAMP-treated cells (Fig. 5). Similarly, cells treated with cAMP and then histamine had $0.09 \pm 0.02$ (isoform B) and $0.08 \pm 0.02$ (isoform A) fewer mol phosphate/mol light chain than did control cells (Fig. 5).

The effect of histamine on cellular cAMP. The rapid return of MLC phosphorylation to control levels would be enhanced if histamine increased cellular cAMP as well as increasing cell calcium. Basal cAMP levels $\left(2.9 \pm 0.89 \mathrm{pmol} / 4.9 \mathrm{~cm}^{2}\right.$ of confluent cells $)$ did not change at $30 \mathrm{~s}\left(2.9 \pm 0.40 \mathrm{pmol} / 4.9 \mathrm{~cm}^{2}\right)$, $90 \mathrm{~s}\left(3.9 \pm 0.84 \mathrm{pmol} / 4.9 \mathrm{~cm}^{2}\right)$, or $5 \mathrm{~min}(2.3 \pm 0.07 \mathrm{pmol} / 4.9$ $\left.\mathrm{cm}^{2}\right)$ after exposure to histamine. However, forskolin $(2 \times$ $\left.10^{-5} \mathrm{M}\right)$ and aminophyline $\left(10^{-3} \mathrm{M}\right)$ increased HUVEC cAMP $\left(18.8 \pm 2.6 \mathrm{pmol} / 4.9 \mathrm{~cm}^{2}\right) 5 \mathrm{~min}$ after exposure.

\section{Determining the kinase that mediates $M L C_{20}$ phosphorylation}

Two-dimensional TLC peptide mapping. Histamine increases both calcium and DAG in HUVECs. Conceivably, histamine could initiate $\mathrm{MLC}_{20}$ phosphorylation by MLCK (calcium dependent) and / or by PKC (calcium and DAG dependent). To directly determine which kinase phosphorylated $\mathrm{MLC}_{20}$ in HUVECs exposed to histamine we compared maps of tryptic digests of $\mathrm{MLC}_{20}$ standards phosphorylated in vitro by MLCK and by PKC to peptide maps of tryptic digests of $\mathrm{MLC}_{20}$ phosphorylated in situ in control and histamine-exposed HUVECs.

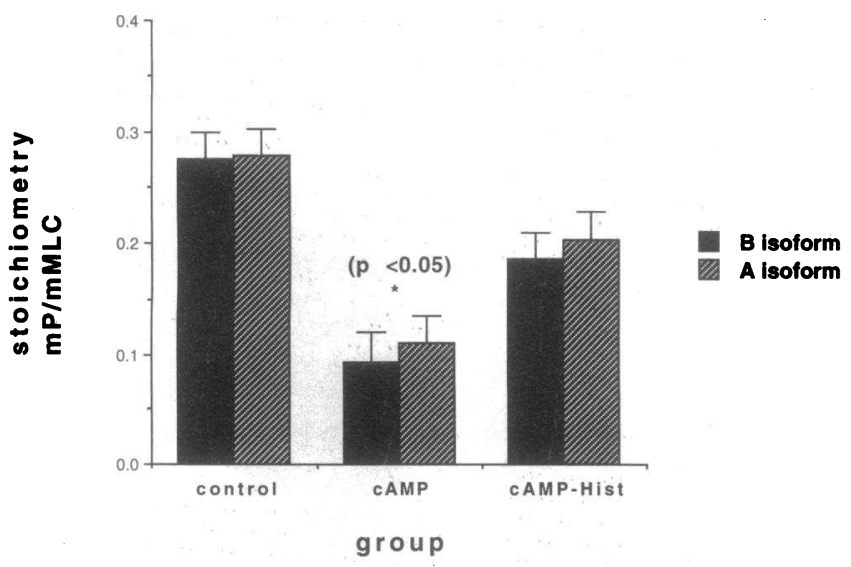

Figure 5. Number of moles of phosphate per mole of MLC ( $\mathrm{mol}$ $\mathrm{P} / \mathrm{mol} \mathrm{MLC}_{20}$ ) in control HUVECs (Con), in HUVECs exposed to 8-Br-cAMP $\left(10^{-4} \mathrm{~mol} /\right.$ liter $)$ for $10 \mathrm{~min}(c A M P)$, and in HUVECs exposed to 8 -Br-cAMP $\left(10^{-4} \mathrm{~mol} /\right.$ liter for $\left.10 \mathrm{~min}\right)$ and then histamine $\left(10^{-5} \mathrm{~mol} /\right.$ liter $)$ for $30 \mathrm{~s}$. 8-Br-cAMP alone decreased the amount of phosphorylation from control cells $(P<0.05)$. Pretreatment with 8-Br-cAMP prevented an increase in $\mathrm{MLC}_{20}$ phosphorylation when cells were exposed to histamine. $n \geq 15$ for each condition.
In vitro standards were generated by phosphorylating turkey gizzard smooth muscle MLC or human platelet MLC with smooth muscle MLCK or rat brain PKC (each kinase displayed the same map whether smooth muscle or nonmuscle MLC was used). Fig. 6 shows the two-dimensional TLC peptide map of tryptic fragments from turkey gizzard $\mathrm{MLC}_{20}$ phosphorylated in vitro by MLCK and PKC. The map of the MLCK standard (Fig. 6 a) consisted of a single dominant phosphorylated peptide fragment (peptide A), which contained only phosphoserine. The migration of this fragment was consistent with that of a fragment previously identified as containing phosphorylated $\operatorname{ser}^{19}$ (14). The map of the PKC standard (Fig. $6 b$ ) demonstrated three peptides. Peptide B, a minor peptide, contained only phosphoserine. Peptide $\mathrm{C}$, a major peptide, also contained only phosphoserine. The migration of these fragments is consistent with that of fragments previously identified as containing monophosphorylated $\operatorname{ser}^{1}$ or $\operatorname{ser}^{2}(14)$. Peptide $\mathrm{D}$ is a major peptide that contains only phosphothreonine, and its migration is consistent with previous reports of a fragment containing monophosphorylated thr ${ }^{9}$ (14).

Tryptic fragments of $\mathrm{MLC}_{20}$ phosphorylated in situ in HUVECs demonstrated a phosphorylated tryptic peptide (peptide 1, Fig. $7 A$ ) similar to the one obtained with the MLCK standard. The peptide map of digest from control HUVECs also demonstrated another phosphorylated tryptic peptide (peptide 2, Fig. $7 A$ ). Peptide 1 migrated to a similar position as the monophosphorylated $\operatorname{ser}^{19}$ in vitro standard. Peptide 2 was positioned near the origin, a migration pattern previously identified for a tryptic fragment diphosphorylated on $\mathrm{thr}^{18}$ and $\operatorname{ser}^{19}$ (24). This pattern is unaltered even if repeated digestion is extended for $48 \mathrm{~h}$. When digest from control cells was mixed with digest from the MLCK standard and separated by the same two-dimensional TLC procedures, peptide 1 comigrated with the monophosphorylated $\operatorname{ser}^{19}$ standard (Fig. $7 B$ ), confirming that peptide 1 represented a monophosphorylated peptide phosphorylated in situ by MLCK. Maps of $\mathrm{MLC}_{20}$ tryptic fragments from HUVECs exposed to histamine demonstrated the same two peptides as control cells (Fig. $7 C$ ). When digests from control cells and histamine-stimulated cells were mixed, the maps showed comigration of both peptides, indicating that MLCK mediates both basal and histamine-stimulated phosphorylation (Fig. $7 \mathrm{D}$ ). Monophosphorylated $\operatorname{ser}^{10 \mathrm{r} 2}$ peptides were not observed under resting and histamine-stimulated conditions. This indicates that PKC does not mediate phosphorylation in HUVECs under basal and histamine-stimulated conditions. In addition, phorbol dibutyrate PDBU $\left(10^{-6} \mathrm{M}\right)$-exposed cells did not generate significant $\operatorname{ser}^{10 r 2}$ fragments (data not shown).

The peptide map pattern did not change in cells exposed to cAMP agonists (Fig. $7 \mathrm{E}$ ). Two-dimensional TLC maps of digests of cAMP-stimulated cells revealed a peptide (peptide 1) that comigrated with the monophosphorylated $\operatorname{ser}^{19}$ standard (Fig. $7 F$ ). Since cAMP decreased phosphorylation, and the peptide map was unaltered, cAMP decreased phosphorylation by decreasing MLCK activity and/or increasing dephosphorylation of $\mathrm{MLC}_{20}$.

Phosphoamino acid analysis of in situ phosphorylated peptides. When peptides from two-dimensional TLC maps of unstimulated cells are eluted from the silica TLC plates and subjected to phosphoamino acid analysis, peptide 1 contained phosphoserine and phosphothreonine (Fig. 8). Since peptide 1 also comigrates with the monophosphorylated $\operatorname{ser}^{19}$ standard, 


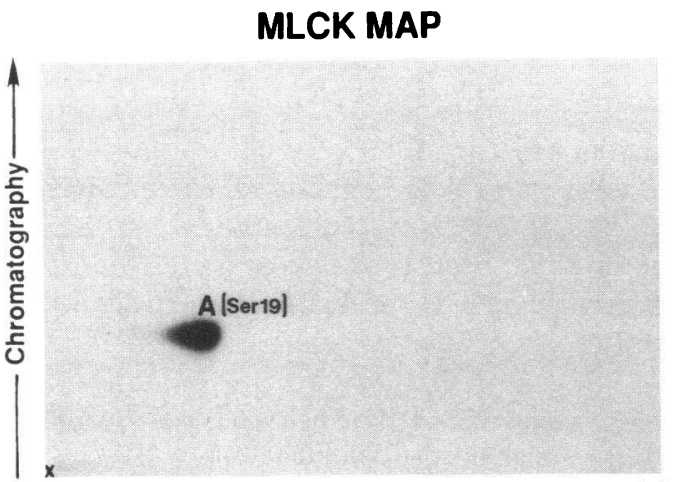

$(+)$

b

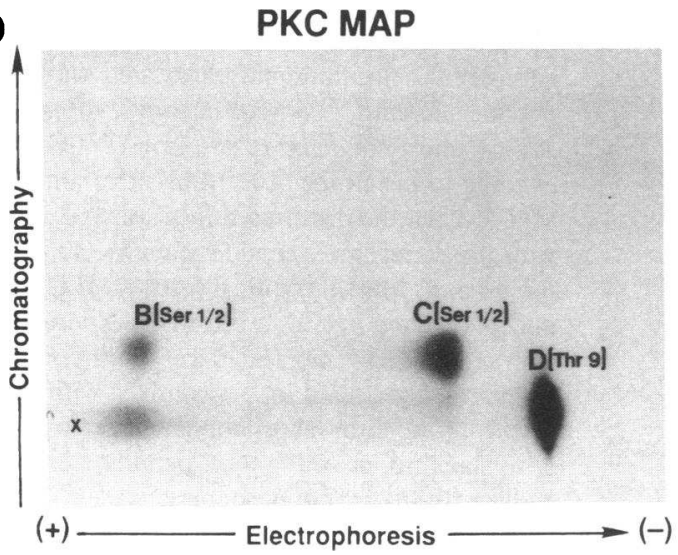

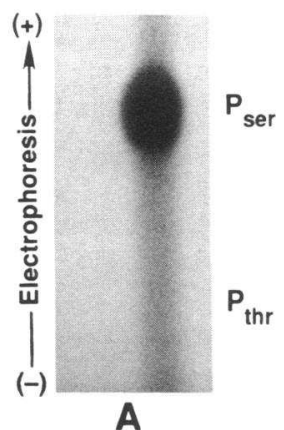

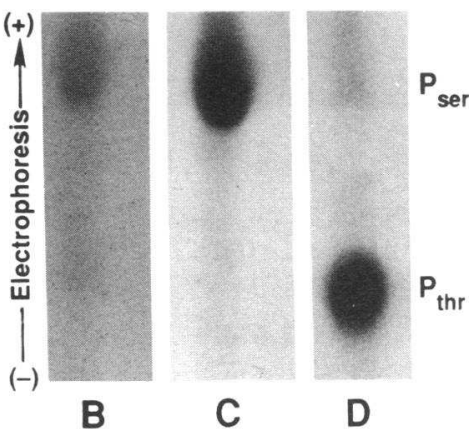

Figure 6. Maps of tryptic digests of turkey gizzard MLC phosphorylated in vitro by $\operatorname{MLCK}(a)$ or by rat brain PKC (b). See text for explanation of maps and phosphoamino acid analysis. this suggests that peptide 1 is a mixture of monophosphorylated peptides that contained monophosphorylated $\operatorname{ser}^{19}$ and monophosphorylated thr ${ }^{18}$ peptides. Peptide 2 contains phosphoserine and phosphothreonine. As noted above, peptide 2 has been previously demonstrated to be a diphosphorylated $\operatorname{ser}^{19}$ and $\operatorname{thr}^{18}$ peptide (24). This phosphoamino acid analysis pattern is similar in histamine-stimulated cells (data not shown). The presence of phosphothreonine in peptide 1 suggest that, unlike smooth muscle cells, monophosphorylation at $\mathrm{thr}^{18}$ by MLCK significantly occurs in the HUVEC.

\section{Discussion}

The intent of these experiments was to further explain how inflammatory molecules such as histamine cause adjacent endothelial cells to retract from each other (1-8) and how cAMP agonists oppose this response $(2,25)$. Although the actin cytoskeleton of permeabilized endothelial cells contract after the addition of $100 \mu \mathrm{M}$ calcium, ATP, MLCK, and calmodulin $(10,11,13)$, very little contraction and $\mathrm{MLC}_{20}$ phosphorylation occurs at $1-5 \mu \mathrm{M}$ free calcium in these permeabilized cell models (13). The limited contraction of endothelial cell cytoskeletons at $1-5 \mu \mathrm{M}$ calcium is especially relevant, since cell calcium remains in the high nanomolar range in stimulated endothelial cells. Histamine increased calcium in HUVECs to $\sim 650 \mathrm{nM}$ in our earlier report, and this is consistent with other reports on histamine stimulation of HUVECs and the response of endothelial cell calcium to other inflammatory molecules such as bradykinin $(2,26,27)$.

In the experiments described in this manuscript we found that doses of histamine that increased HUVEC monolayer per- meability to albumin by $50-100 \%$, increased $\mathrm{MLC}_{20}$ phosphorylation by $\sim 0.2 \mathrm{~mol}$ phosphate $/ \mathrm{mol} \mathrm{MLC}_{20}$ (approximately a 90\% increase from baseline). Unstimulated HUVECs demonstrated constitutive phosphorylation. Histamine caused a rapid but transient increase in $\mathrm{MLC}_{20}$ phosphorylation and achieved maximal levels by $30 \mathrm{~s}$. Maximal levels persisted at $90 \mathrm{~s}$ but returned to basal levels by $5 \mathrm{~min}$. Of note is that the maximal levels of $\mathrm{MLC}_{20}$ phosphorylation in histamine-stimulated HUVECs is consistent with observed maximal changes in cell calcium. We and others have observed that histamine-stimulated increases in calcium are maximal by $15-30 \mathrm{~s}$ in $\operatorname{HUVECs}(2$, 28). The close temporal relationship between change in cell calcium and $\mathrm{MLC}_{20}$ phosphorylation in HUVE suggest a calcium dependence for $\mathrm{MLC}_{20}$ phosphorylation.

It does not seem likely that the modest increase in $\mathrm{MLC}_{20}$ phosphorylation we observed represents a methodological problem. Exposing the cells to $5 \mu \mathrm{M}$ ionomycin produced an appropriately greater increase in $\mathrm{MLC}_{20}$ phosphorylation (0.5 mol phosphate $/ \mathrm{mol} \mathrm{MLC}_{20}$ ), and one that is similar to that observed in smooth muscle cells exposed to $10 \mu \mathrm{M}$ ionomycin for the same time $\left(0.6 \mathrm{~mol}\right.$ phosphate $\left./ \mathrm{mol} \mathrm{MLC}_{20}, 90 \mathrm{~s}\right)(16)$. Similarly, the levels of phosphorylation achieved in stimulated smooth muscle cells at time points earlier than $30 \mathrm{~s}$ were preserved at $30 \mathrm{~s}$, so it is not likely that we missed higher levels of phosphorylation at earlier time points (16). The increase in cell calcium observed in HUVECs stimulated with histamine is also preserved at these times (26).

Since the level of $\mathrm{MLC}_{20}$ phosphorylation should reflect the amount of isometric tension exerted on the underlying extracellular matrix, one would predict that unstimulated HUVECs should exert resting isometric tension since they display consti- 

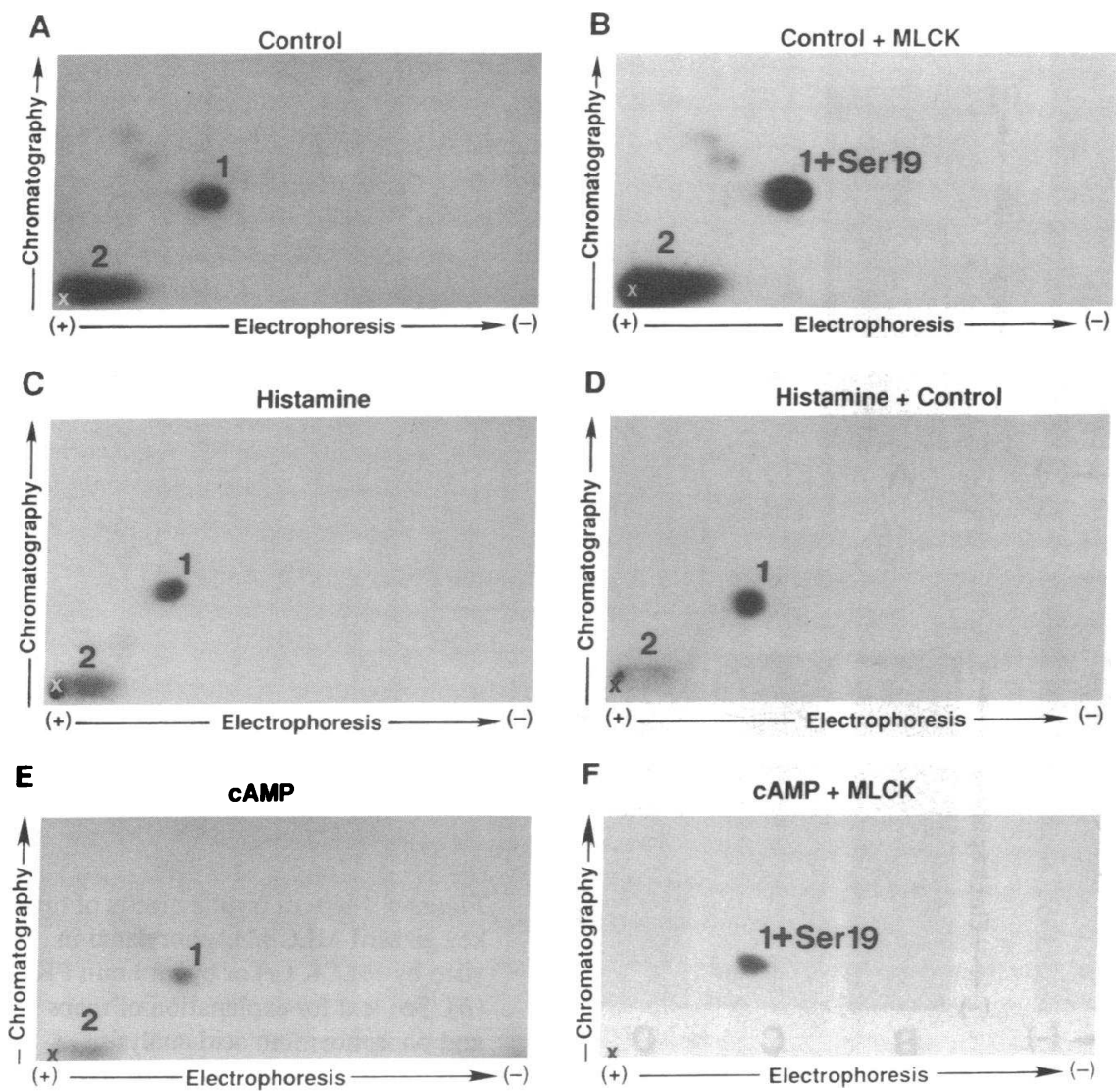

Figure 7. (A) Map of tryptic digests of $\mathrm{MLC}_{20}$ phosphorylated in situ in control HUVECs. Two peptides, peptide 1 and peptide 2 were observed. ( $B$ ) When the digest used in $A$ was mixed with digest from $M_{2} C_{20}$ phosphorylated in vitro with MLCK as in Fig. $6 a$, peptide 1 comigrates with monophosphorylated $\operatorname{ser}^{19}$ peptide standard. $(C)$ Map of tryptic digest of $\mathrm{MLC}_{20}$ phosphorylated in situ in HUVECs exposed to histamine $\left(10^{-5} \mathrm{~mol} /\right.$ liter $)$ for 30 s. (D) When the digest used in $A$ was mixed with the digest in $C$, peptide maps are superimposed. $E$. Map of tryptic digests of $\mathrm{MLC}_{20}$ phosphorylated in situ in HUVECs exposed to 8-Br-cAMP $\left(10^{-4} \mathrm{~mol} /\right.$ liter $)$ for $10 \mathrm{~min} . F$. When the digest used in $E$ was mixed with digest from the monophosphorylated $\operatorname{ser}^{19}$ in vitro standard, as in Fig. $6 a$, peptide 1 comigrates with the monophosphorylated $\operatorname{ser}^{19}$. See text for explanation for maps generated under different conditions. tutive $\mathrm{MLC}_{20}$ phosphorylation. In addition, the amount of isometric tension would be expected to increase in proportion to the increase in phosphorylation that results from receptor activation of inositol phospholipid hydrolysis (29). We found that histamine activation of HUVEC inositol phospholipid hydrolysis increased $\mathrm{MLC}_{20}$ phosphorylation $0.18 \mathrm{~mol} / \mathrm{mol} \mathrm{MLC}_{20}$, a $90 \%$ increase. Thrombin, which also activates HUVEC inositol phospholipid hydrolysis, increased HUVEC centripetal tension from 0.65 to $1.3 \times 10^{5} \mathrm{dyn} / \mathrm{cm}^{2}$ in Kolodney and Wysolmerski's report (30). Similarly, Boswell et al. (31) and Morel et al. (32) have observed that unstimulated bovine pulmonary

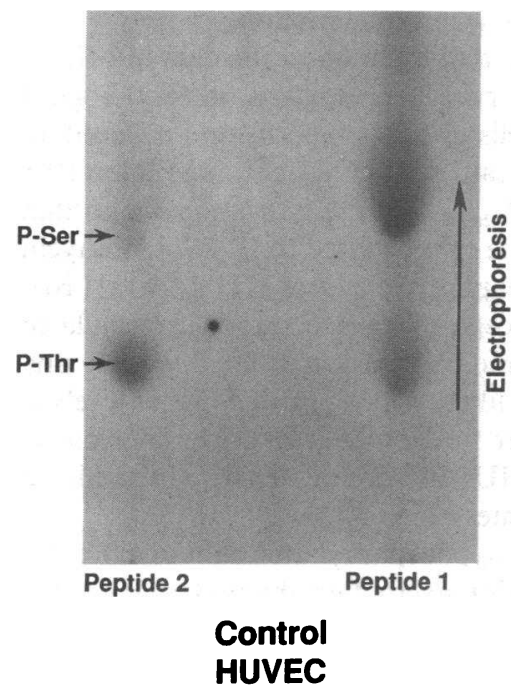

Figure 8. Autoradiogram of phosphoamino acids from peptide 1 and peptide 2 from control HUVECs. See text for explanation. microvascular endothelial cells display constitutive wrinkling of silicone rubber matrix and further wrinkle when cells are exposed to vasoactive mediators. Therefore, the change in $\mathrm{MLC}_{20}$ phosphorylation and isometric tension is consistent with the hypothesis that activation of signal transduction may mediate an acute increase in isometric tension through the cytoskeleton.

In our experiments peak phosphorylation of $\mathrm{MLC}_{20}$ was observed $30 \mathrm{~s}$ after adding histamine. Kolodney and Wysolmerski (30) observed an increase in tension exerted by HUVEC monolayers $30 \mathrm{~s}$ after adding thrombin. These relationships are consistent with $\mathrm{MLC}_{20}$ phosphorylation contributing to the initiation of increased tension development in HUVECs. However, Kolodney and Wysolmerski (30) found that peak tension developed after $5 \mathrm{~min}$ and persisted for $\geq 40 \mathrm{~min}$ after adding thrombin. We found that $\mathrm{MLC}_{20}$ phosphorylation had returned to basal levels by $5 \mathrm{~min}$ and remained there at $15 \mathrm{~min}$. Maintaining tension even after $\mathrm{MLC}_{20}$ phosphorylation approaches basal levels may be analogous to smooth muscle cells (29). Other effects of activation of the signal transduction cascade, such as recruitment of the actin cytoskeleton, may also contribute to the persistent tension (17). Similar to what Fox and Phillips (33) found in platelets, Carson et al. (34) recently found that histamine increased the fraction of actin that was present as filamentous actin in HUVECs.

To explain the transient increase in $\mathrm{MLC}_{20}$ phosphorylation in HUVECs exposed to histamine, we asked whether $\mathrm{MLC}_{20}$ phosphorylation returns to baseline because cell cAMP levels increase. Hekimian et al. (35) recently demonstrated that histamine increased cell cAMP levels in bovine aortic endothelial cells through a $\mathrm{H}_{2}$ receptor. We did not observe any 
significant increase in cell cAMP from baseline in HUVECs exposed to histamine.

As noted above, histamine increases both calcium and diacylglycerol in HUVECs. Hence, histamine could activate calcium-calmodulin-dependent kinases (MLCK) or DAG-dependent kinases (PKC). Since PKC-mediated MLC phosphorylation has been associated with platelet and basophil activation, it was of interest to us to determine which kinase was responsible for phosphorylation of $\mathrm{MLC}_{20}$ in HUVECs, both at rest and after stimulation with histamine $(14,15)$. We found that both basal and histamine-stimulated $\mathrm{MLC}_{20}$ phosphorylation in HUVECs were mediated by MLCK, and we found no evidence for MLC phosphorylation by PKC in HUVECs, even when the cells were stimulated with PDBU.

We previously found that increasing HUVEC cAMP decreased basal permeability and prevented histamine from increasing the permeability of HUVEC monolayers but did not prevent the increase in cell calcium (2). In the current experiments we found that increasing HUVEC cAMP markedly reduced phosphorylation of $\mathrm{MLC}_{20}$ and prevented an increase with histamine. Hence, the effect of cAMP on histamine stimulation of $\mathrm{MLC}_{20}$ phosphorylation correlates with our earlier report on in vitro permeability (2). We also observed that MLCK mediates $\mathrm{MLC}_{20}$ phosphorylation under CAMP-stimulated conditions. Our data suggest that A kinase modulates $\mathrm{MLC}_{20}$ phosphorylation indirectly by either decreasing the basal activity of MLCK or enhancing phosphatase activity (17, 36). Conti and Adelstein (37) has shown that A kinase can phosphorylate and decrease MLCK activity. Phosphorylated MLCK binds poorly to the calcium-calmodulin complex, and contraction is prevented even when signal transduction is activated. On the basis of our results, it is conceivable that modulation of MLCK activity may be an important regulatory step in the control of endothelial barrier function.

In reports from others and ourselves, cAMP reduces the basal permeability of monolayers of endothelial cells $(2,25$, 38). Whether a decrease in the level of $\mathrm{MLC}_{20}$ phosphorylation enhances endothelial barrier function is unclear. Using silicon rubber matrix, other investigators have shown that increasing cell cAMP induces matrix relaxation $(31,32)$. If centripetal isometric tension opposes tethering forces that link cells and substrate together, then, perhaps, a decrease in $\mathrm{MLC}_{20}$ phosphorylation could decrease opposing tension on tethering forces which, in turn, could enhance adhesive forces between adjacent cells and cells to substrate. This could enhance barrier function. However, other effects of A kinase activation independent of MLC phosphorylation could also contribute to the enhanced barrier function, and it is not yet certain if cAMP prevents the response to histamine only by reducing $\mathrm{MLC}_{20}$ phosphorylation or whether there are also other effects of cAMP that may prevent the increase in permeability (2).

Earlier reports of MLCK-mediated phosphorylation of $\mathrm{MLC}_{20}$ had identified $\operatorname{ser}^{19}$ as the preferred site of MLCK phosphorylation both in situ and in vitro in smooth muscle $(24,39$, $40)$. The thr ${ }^{18}$ site has been shown to be diphosphorylated only under extreme in vitro conditions (39). However, phosphoamino acid analysis of the monophosphorylated peptide from HUVECs demonstrated phosphothreonine, suggesting that $\mathrm{thr}^{18}$ may be an acceptable monophosphorylation site in HUVECs. It is unclear what effect monophosphorylation at thr ${ }^{18}$ would have on the actin-stimulated myosin ATPase activity compared with monophosphorylation at ser ${ }^{19}$. Diphosphory- lation at thr ${ }^{18}$ has been shown to augment and to have no effect on actomyosin contraction (24, 40-42). Protein sequencing of the threonine phosphorylated fragment will be necessary to confirm the identity of the monophosphorylated thr ${ }^{18}$ peptide.

The isoelectric focusing patterns of the $\mathrm{MLC}_{20}$ isoforms from HUVECs were similar to, but not the same as, those reported in human platelets and smooth muscle $(14,22)$. HUVECs demonstrated two $16-\mathrm{kD}$ isoforms whereas in platelets there was only one $16-\mathrm{kD}$ isoform. Also the isoform pattern of the $20-\mathrm{kD}$ isoforms is unique. Other work has suggested that MLCs of nonmuscle cells may be encoded by different genes than those in smooth muscle cells (43). Our own observations would suggest that there are subtle differences among the isoforms in smooth muscle, platelets, and endothelial cells, and these differences could contribute to differences in functional response.

In summary, doses of histamine that increase the permeability of monolayers of HUVECs caused a modest increase in $\mathrm{MLC}_{20}$ phosphorylation in HUVECs, and the phosphorylation was mediated by MLCK. The amount of histamine-stimulated phosphorylation was consistent with the increase in HUVEC calcium that occurs with histamine stimulation, and further increases in cell calcium with ionomycin caused an appropriately greater increase in $\mathrm{MLC}_{20}$ phosphorylation. Increases in cell cAMP reduced basal phosphorylation of $\mathrm{MLC}_{20}$ and prevented the histamine-stimulated increase in $\mathrm{MLC}_{20}$ phosphorylation. Although these data are consistent with the hypothesis that $\mathrm{MLC}_{20}$ phosphorylation contributes to retraction of $\mathrm{HU}$ VECs stimulated with histamine, it does not rule out other mechanisms that may regulate cell retraction during inflammation independent of actomyosin contraction.

\section{Acknowledgments}

Dr. Moy is a recipient of a Training Fellowship Grant from the American Heart Association-Iowa Affiliate and the National Heart, Lung, and Blood Institute. This work was completed during Dr. D. M. Shasby's tenure as a Clinical Investigator and Dr. Scott's tenure as a Research Associate of the Veterans Administration. The work was also supported by National Institutes of Health grant HL-33540 and American Lung Research grant 35131.

\section{References}

1. Albertine, K. H., J. Weiner-Kronish, K. Koike, and N. C. Staub. 1984. Quantification of damage to lung microvessels in anesthetized sheep. J. Appl. Physiol. 57:1360-1368.

2. Carson, M., S. Shasby, and D. M. Shasby. 1989. Histamine and inositol phosphate accumulation in endothelium: cAMP and G-protein. Am. J. Physiol. 257:L259-L264.

3. Laposata, M., D. Dovnarsky, and H. Shin. 1983. Thrombin-induced gap formation in confluent endothelial cell monolayers in vitro. Blood. 62:549-556.

4. Majno, G., and G. Palade. 1961. Studies on inflammation. 1. Effect of histamine and serotonin on vascular permeability: an electron microscopic study. J. Biophys. Biochem. Cytol. 11:571-605.

5. Shasby, D. M., S. Lind, S. Shasby, J. Goldsmith, and G. Hunninghake. 1985. Reversible oxidant-induced increases in albumin transfer across cultured endothelium: alterations in cell shape and calcium homeostasis. Blood. 65:605614.

6. Shasby, D. M., S. Shasby, J. Sullivan, and M. Peach. 1982. Role of endothelial cell cytoskeleton in control of endothelial permeability. Circ. Res. 51:657661 .

7. Shasby, D. M., and S. Shasby. 1986. Effects of calcium on transendothelial albumin transfer and electrical resistance. J. Appl. Physiol. 60:71-79.

8. Wysolmerski, R., and D. Lagunoff. 1985. The effect of ethchlorvynol on cultured endothelial cells-a model for the study of the mechanism of increased vascular permeability. Am. J. Pathol. 119:505-512.

9. Nicolaysen, G. 1971. Intravascular concentrations of calcium and magne- 
sium ions and edema formation in isolated lungs. Acta Physiol. Scand. 81:325339.

10. Schnittler, H., A. Wilke, T. Gress, N. Suttorp, and D. Drenckhahn. 1990 Role of actin and myosin in the control of paracellular permeability in pig, rat and human vascular endothelium. J. Physiol. 431:379-401.

11. Wysolmerski, R., and D. Lagunoff. 1990. Involvement of myosin light chain kinase in endothelial cell retraction. Proc. Natl. Acad. Sci. USA. 87:16-20.

12. Wysolmerski, R., and D. Lagunoff. 1988. Inhibition of endothelial cell retraction by ATP depletion. Am. J. Pathol. 132:28-37.

13. Wysolmerski, R., and D. Lagunoff. 1991. Regulation of permeabilized endothelial cell retraction by myosin phosphorylation. Am. J. Physiol. 261:C32C40.

14. Kawamoto, S., A. Bengur, J. Sellers, and R. Adelstein. 1989. In situ phosphorylation of human platelet myosin heavy and light chains by protein kinase $C$. J. Biol. Chem. 264:2258-2265.

15. Ludowyke, R., I. Peleg, M. Beaven, and R. Adelstein. 1989. Antigen-induced secretion of histamine and the phosphorylation of myosin by protein kinase C in rat basophilic leukemic cells. J. Biol. Chem. 264:12492-12501.

16. Taylor, D., and J. Stull. 1988. Calcium dependence of myosin light chain phosphorylation in smooth muscle cells. J. Biol. Chem. 263:14456-14462.

17. Lamb, N., A. Fernandez, M. Conti, R. Adelstein, D. Glass, W. Welch, and J. Feramisco. 1988. Regulation of actin microfilament integrity in living nonmuscle cells by cAMP-dependent protein kinase and the myosin light chain kinase. J. Cell Biol. 106:1955-1971.

18. Daniel, J., and R. Adelstein. 1976. Isolation and properties of platelet myosin light chain kinase. Biochemistry 15:2370-2377.

19. Sellers, J., M. Soboeiro, K. Fraust, A. Bengur, and E. Harvey. 1988. Preparation and characterization of heavy meromyosin and subfragment 1 from vertebrate cytoplasmic myosin. Biochemistry. 27:6977-6982.

20. Isaacs, W., and A. Fulton. 1987. Cotranslational assembly of myosin heavy chain in developing cultured skeletal muscle. Proc. Natl. Acad. Sci. USA 84:6174-6178.

21. Gracy, R. 1977. Two dimensional thin layer methods. Methods Enzymol. 47:195-204.

22. Singer, H. 1990. Protein kinase $\mathrm{C}$ activation and myosin light chain phosphorylation in 32P-labeled arterial smooth muscle. Am. J. Physiol. 259:C631C639.

23. Wilson, J., M. Winter, and D. Shasby. 1990. Oxidants, ATP depletion, and endothelial permeability to macromolecules. Blood. 76:2578-2582.

24. Haeberle, J., T. Sutton, and B. Trockman. 1988. Phosphorylation of two sites on smooth muscle myosin: effects on contraction of glycerinated vascular smooth muscle. J. Biol. Chem. 263:4424-4429.

25. Stelzner, T., J. Weil, and R. O'Brien. 1989. Role of cyclic adenosine monophosphate in the induction of endothelial barrier properties. J. Cell. Physiol. 139:157-166.

26. Jacob, R., J. Meritt, T. Hallam, and T. Rink. 1988. Repetitive spikes in cytoplasmic calcium evoked by histamine in human endothelial cells. Nature (Lond.). 335:40-45.
27. Schilling, W. 1989. Effect of membrane potential on cytosolic calcium of bovine aortic endothelial cells. Am. J. Physiol. 257:H778-H784.

28. Rotrosen, D., and J. Gallin. 1986. Histamine type I receptor occupancy increases endothelial cytosolic calcium, reduces F-actin, and promotes albumin diffusion across cultured endothelial monolayers. J. Cell. Biol. 103:2379-2387.

29. Hai, C., and R. Murphy. 1988 . $\mathrm{Sr}^{2+}$ activates cross-bridge phosphorylation and latch state in smooth muscle. Am. J. Physiol. 255:C401-C407.

30. Kolodney, M., and R. Wysolmerski. 1992. Isometric contraction by fibroblasts and endothelial cells in tissue culture: a quantitative study. J. Cell Biol. 117:73-82.

31. Boswell, C., G. Majno, I. Joris, and K. Ostrom. 1992. Acute endothelial cell contraction in vitro: a comparision with vascular smooth muscle cells and fibroblasts. Microvasc. Res. 43:178-191.

32. Morel, N., A. Dodge, W. Patton, I. Herman, H. Hechtman, and D. Shepro. 1989. Pulmonary microvascular endothelial cell contractility on silicone rubber substrate. J. Cell. Physiol. 141:653-659.

33. Fox, J., and D. Phillips. 1982. Role of phosphorylation in mediating the association of myosin with the cytoskeletal structures of human platelets. J. Biol. Chem. 257:4120-4126.

34. Carson, M., S. Shasby, S. Lind, and D. M. Shasby. 1992. Histamine, actin-gelsolin binding and polyphosphoinositides in human umbilical vein endothelial cells. Am. J. Physiol. (Lung Cell Mol. Physiol. 7) 263:L664-L669.

35. Hekimian, G., S. Cote, J. V. Sande, and J. M. Boeynaems. $1992 . \mathbf{H}_{2}$ receptor-mediated responses of aortic endothelial cells to histamine. Am. J. Physiol. 262:H220-H224

36. DeLanerolle, P., M. Nishikawa, D. Yost, and R. Adelstein. 1984. Increased phosphorylation of myosin light chain kinase after an increase in cyclic AMP in intact smooth muscle. Science (Wash. DC). 223:1415-1417.

37. Conti, M., and R. Adelstein. 1980. Phosphorylation by cyclic adenosine 3':5'-monophosphate dependent protein kinase regulates myosin light chain kinase. Fed. Proc. 39:1569-1573.

38. Langeler, E., and V. VanHinsbergh. 1991. Norepinephrine and iloprost improve barrier function of human endothelial cell monolayers: role of cAMP. Am. J. Physiol. 260:C1052-C1059.

39. Ikebe, M., and D. Hartshorne. 1985. Phosphorylation of smooth muscle myosin at two distinct sites by myosin light chain kinase. J. Biol. Chem. 260:10027-10031

40. Umemoto, S., A. Bengur, and J. Sellers. 1989. Effect of multiple phosphorylation of smooth muscle and cytoplasmic myosin in an in vitro motility assay. J. Biol. Chem. 264:1431-1436.

41. Ikebe, M. 1989. Phosphorylation of a second site for myosin light chain kinase on platelet myosin. Biochemistry 28:8750-8755.

42. Itoh, K., T. Hara, and N. Shibata. 1992. Diphosphorylation of platelet myosin by myosin light chain kinase. Biochim. Biophys. Acta. 1133:286-292.

43. Kumar, C., S. Mohan, P. Zavodny, S. Narula, and P. Leibowitz. 1989. Characterization and differential expression of human vascular smooth muscle myosin light chain 2 isoform in nonmuscle cells. Biochemistry. 28:4027-4035. 